\title{
DEMANDA E RESPOSTA
}

André Ricardo Vier Botti

SUMÄRIO: 1. Introdução. 2. Demanda. 2.1. Conceito. 2.2. Elementos Constitutivos da Demanda. 2.3. Cumulaça de Demandas. 3. Resposta. 3.1. Conceto. 3.2. Revelia. 3.3. Reconhecimento Jurídico do Pedido. 3.4. Defesa. 3.5. Reconvengão. 4.Conclusão. 5. Bibliografia.

SUMMARY: 1. Introduction. 2. Demand. 2.1. Concept. 2.2. Demand Constiment Elements. 2.3.Demand Accumulation. 3. Response. 3.1. Concept. 3.2. Default. 3.3. Juridical Recognition of the Request. 3.4. Defence 3.5 . Reproach. 4. Conclusion. 5.Bibliography.

SUMARIO: 1. Introducción. 2. Demanda. 2.1. Concepto. 2.2. Elementos Contitutivos de la Demanda. 2.3. Acumulación de Demanda. 3.Respuesta. 3.1. Concepto. 3.2.Rebeldia. 3.3. Reconocimiento Juridico del Pedido. 3.4.Defesa. 3.5. Reconvención. 4. Conclusion. 5. Bibliografia.

RESUMO: O artigo trata do binômio demanda e resposta sob a perspectiva do processo como tutcla bilateral, onde tanto o autor quanto o réu deduzem uma demanda inicial, que delimita toda a atividade jurisdicional. $O$ autor objetiva que a resistência do téu seja declarada injustificada e cesse, por seu turno, o réu pretende a declaração de que é justa a sua contraposição a pretensão do demandante. De tal forma, o Estado virá intervir para, imparcialmente, indicar qual postura há de prevalecer, pacificando o conflito.

ABSTRACT: The present article is about the binomial demands and responses under the perspective of the process as a bilateral tutelage where the athor as well as the defendant require an initial demand which delimits the whole juriscdictional activity. The author expects the defendant's reluctancy to be declared and injustified. The defendant on the other hand claims his contraposition to the demander's intention is just. Therefore, the State will have intervene in order to fairly indicate which posture should prevail and by doing so pacify the dispute.

* Mestrando em Direito Negocial na Universidade Estadual de LondrinatPR. 
RESUMEN: El presente articulo presenta el binomio demanda y respuesta sob la perspectiva del proceso como una tutela bilateral donde el autor así como el acusado requieren una demanda inicial la cuál delimita toda la actividad jurisdiccional. El autor espera que la resistencia del acusado sea declarada injustificada y que sea suspendida. El acusado por otra parte alega que la sua contraposición a la intención del demandante es justa. Por lo tanto el Estado tendrá que intervenir a fin de indicar de manera justa cuál postura debería prevalecer y así pacificar el conflicto.

PALAVRAS-CHAVE: Demanda. Resposta. Pretensão. Bilateralidade do processo.

KEY-WORDS: Demand. Response. Intention. Lawsuit bilaterality.

PALAVRAS-LLAVES: Demanda. Respuesta. Intención. Bilateralidad del proceso.

\section{Introdução}

O processo visa a satisfação de uma pretensão resistida, cuja demanda é o instrumento para exigir que a tutela jurisdicional atue, formulando uma norma jurídica concreta e individual para o caso, o que culmina com a pacificação do conflito.

Aduzir uma pretensão em Juízo significa pedir a prolatação de um provimento jurisdicional que substituirá os sujeitos em conflito para eliminar a resistência do demandado, já que foi vedada a autotutela.

Porém, o ato de demandar, além de ser o estopim da atividade jurisdicional, fixa os limites da mesma, isto é, ao Estado caberá prestar apenas o tipo de tutela que lhe foi pedida, que será o parâmetro da controvérsia sobre a qual o juiz pode e deve se pronunciar.

Contudo, a concepção de demanda extrapola o ato inicial de provocação da jurisdição, pois abrange todo e qualquer pedido feito em juízo.

Assim, ante a marcha processual, ocorre um suceder de postulações de ambas as partes e de terceiros durante o processo, que são demandas incidentes, por não terem o condão de formá-lo, tal qual as demandas iniciais.

Também o demandado formula sua demanda, ao apresentar a defesa, postulando a declaração de que sua resistência é justificada, o que significa, a contrário sendo, o pedido de improcedência da demanda inicial.

A resposta é a oportunidade para que o demandado aduza as razões da sua resistência à pretensão do demandante. 
O binômio demanda e resposta é a premissa da direção contrária dos interesses dos demandantes, representando a bilateralidade do processo, já que a cada demanda inicial ou incidental do demandante existirá a correspondente pretensão do demandado.

Observa-se, então, que a posição de demandante é apenas uma questão de oportunidade e agilidade, pois tanto o demandante quanto o demandado possuem uma pretensão resistida a ser apresentada para solução pelo Estado-Juiz, sendo que aquele que primeiro protocolar sua demanda junto ao órgão judicial assumirá a posição de demandante.

\section{Demanda}

\subsection{Conceito}

Na sua acepção ontológica, demanda significa o ato de pedir ou postular, sendo que demandar em Juízo é um modo de exigir que a tutela jurisdicional se realize ante a pretensão apresentada ao Estado-Juiz, que, por ser inerte, aguarda a provocação do interessado para dar a resposta cabível, formulando uma norma juridica concreta e individual para o caso.

A pretensão significa a exigência de subordinação de um interesse alheio ao interesse próprio, cabendo ao interessado dirigir-se ao Judiciário e pedir-lhe uma solução face à contraposição dos interesses em conflito.

Assim, com a demanda restará provocado o Poder Judiciário para que substitua os sujeitos em conflito pelo Estado trazendo a pacificação ao conflito de interesses qualificado por uma pretensão resistida, conforme apontava Carnelutti.

Cabe ressaltar que os órgãos jurisdicionais são, por sua índole, inertes, pois o exercício espontâneo do poder jurisdicional acabaria sendo contraproducente, já que a finalidade que informa toda a atividade juridica do Estado é a pacificação social e não fomentar conflitos e discórdias.

Ademais, a experiência ensina que quando o próprio luiz toma a iniciativa do processo ele se liga psicologicamente de tal maneira à idéia contida no seu ato que dificilmente teria condições de julgar imparcialmente.

O Estado, então, somente irá intervir quando outros métodos reconhecidos para a solução dos conflitos (conciliação endo ou extraprocessual, autocomposição e, excepcionalmente, a autotutela, por exemplo) não tiverem surtido efeitos.

Portanto, a jurisdição só atuará a pedido de um dos sujeitos do conflito de interesses, tal qual dispõem os artigos $2^{a}$ e 262 do Código de Processo Civil, apresentando a demanda ao Estado, que cuidará de resolve-la. 
O titular de uma pretensão vem a Juízo pedir a prolatação de um provimento que, eliminando a resistência, satisfaça a sua pretensão e com isso elimine o estado de insatisfação.

O ato de demandar é o responsável pela colocação da pretensão diante do juiz, para que a seu respeito o Estado se manifeste, julgando-a na tutela de conhecimento e satisfazendo-a na tutela executiva.

$O$ pedido que a parte formula ao Estado para que este, por meio do juiz, the preste a tutela jurisdicional corresponde à demanda.

A importância da demanda reside, também, no fato de que o Estado só pode prestar o tipo de tutela jurisdicional que lhe foi pedida, representando o parâmetro que define e limita a controvérsia sobre a qual o juiz. pode e deve pronunciar-se. Trata-se do princípio da congruência, em que deve haver rigorosa correspondência entre demanda e sentença, bem como entre pedido e resposta.

A demanda materializa-se pela petição inicial, que contém pretensão bifronte, isto é, de obter o provimento jurisdicional e obter o bem da vida postulado. A pretensão ao bem da vida é que dá motivo à iniciativa de vir a juízo a fim de obter o provimento jurisdicional capaz de propiciar a tutela exposta na petição inicial.

A concepção até agora apresentada se coaduna com o conceito de demanda inicial, porém o procedimento processual é um suceder de postulações de ambas as partes que o Juiz vai solucionando nos momentos adequados.

Além da demanda inicial, que se materializa pela petição inicial, existem demandas incidentes no processo, de iniciativa do próprio autor, do réu, do terceiro que interveio no processo, dentre outros.

As demandas deduzidas no curso do processo por qualquer das partes ou terceiros recaem sobre a relação jurídica processual já formada, não tendo o condão de iniciála, como ocorre com as demandas iniciais, daí o motivo de serem incidentes.

Por isso, não necessariamente demanda é sinônimo de demanda inicial. Temos demandas incidentes, até mesmo dos próprios auxiliares da Justiça, como, por exemplo, quando o perito postula a fixação dos honorários periciais ou o oficial de justiça requer a prorrogação de prazo para cumprir um mandado.

O próprio réu, ao contestar o pedido do autor, ainda na fase postulatória do processo, apresenta uma demanda de improcedencia da 
inicial, tanto que o autor não poderá mais desistir da ação sem a sua anuência, já que ele também aduziu uma demanda da qual o Estado-Juiz deverá se manifestar.

Porém, pela sua indispensabilidade para que a jurisdição atue, a mais relevante das demandas é aquela que dá início ao processo, qualificada, por isso, como demanda por excelência. A demanda inicial é mais estudada, mas cabe advertir que não é a única.

Por fim, importa diferenciar o direito de ação do direito de demandar. Note-se que para o autor possa obter uma sentença terminativa é preciso que venha a juízo com certos requisitos: possibilidade jurídica do pedido, interesse de agir e legitimidade ad causam, vez que ausentes uma dessas condições da ação, o juiz não se pronunciará acerca da pretensão, ensejando a extinção do processo sem julgamento do mérito.

Por seu turno, o direito de demandar é incondicionado. A demanda existe com a simples apresentação da pretensão, ensejadora da formação do processo.

Ainda que o processo não esteja apto a ser apreciado com o intuito de chegar a uma decisão com julgamento do mérito, impondo o indeferimento da petição inicial pelo juiz, a demanda existe.

\subsection{Elementos Constitutivos da Demanda}

Ao Poder Judiciário incumbe conhecer todos os conflitos decorrentes das pretensões insatisfeitas, o que representa inúmeras demandas, para as quais deve haver soluções específicas de forma a pacificar o conflito, impedindo que ele venha a se repetir dentro dos limites em que atividade jurisdicional se manifestou.

Faz-se necessário identificar cada demanda, de forma que possa ser considerada separadamente, o que se dá através dos seus elementos constitutivos.

A especificação dos elementos da demanda estabelece os limites a serem observados na atuação do Judiciário, pois o juiz deverá julgar cada demanda nos limites em que tiver sido proposta, consoante artigo 128 do Código de Processo Civil.

A demanda julgada, nos termos do artigo 460 do Código de Processo Civil, restringe-se às pessoas indicadas no processo, aos fundamentos de fato e de direito lançados na petição inicial e ao bem da vida que o autor postulou, sendo vedado ao juiz conceder provimento de natureza diferente daquele que tiver sido pedido ou outro bem, ainda que em quantidade superior. 
Passaremos a análise dos elementos constitutivos da demanda, quais sejam: as partes, a causa de pedir e o pedido.

As partes da demanda são o sujeito que a propõe e aquele em relação ao qual a demanda é proposta. O primeiro desses sujeitos, por ter formulado a demanda, é chamado de demandante, enquanto o segundo deles, que será alvo de uma pretensão, denomina-se demandado.

A condição do sujeito comparecer em juízo pedindo a tutela jurisdicional em face de outrem já lhes atribui as qualidades de demandante e demandado, respectivamente, ainda que se tratem de partes ilegítimas, o que será verificado antes que o Estado-Juiz se pronuncie de maneira definitiva acerca do litígio.

A qualidade de demandante e demandado implica na sujeição à decisão prolatada no processo, de forma que os efeitos subjetivos da coisa julgada irão lhes atingir diretamente.

A causa de pedir é correlata com a idéia de que todo direito subjetivo acerca de um determinado bem da vida nasce de dois elementos, isto é, um preceito legal e um fato previsto na lei como antecedente lógico para a imposição do referido preceito.

Cabe ao demandante, ao aduzir sua pretensão, explicar quais os fatos que lhe teriam dado direito a obter o bem da vida postulado, bem como $o$ preceito pelo qual os fatos geram o direito afurmado.

Podemos identificar, então, a divisão da causa de pedir em remota e próxima. A causa de pedir remota corresponde aos fatos que o autor alega para demonstrar seu suposto direito e a causa de pedir próxima é a proposta de enquadramento desses fatos em uma categoria jurídico-material.

$O$ demandante justifica o pedido que é feito ao órgão jurisdicional por meio das razōes fáticas e jurídicas do mesmo, que correspondem à causa de pedir remota e próxima, que são as razões do pedido.

O pedido, como elemento identificar da demanda, consubstancia-se em duas vertentes: o pedido imediato e o pedido mediato, um de natureza processual e o outro vinculado ao direito material subjacente à pretensão.

O pedido imediato é a postulação de um provimento jurisdicional de determinada natureza, efetuado pelo demandante, indicando a espécie de sentença que é requerida ao Estado-Juiz (condenatória, declaratória, constitutiva, executiva e mandamental).

Por pedido mediato entende-se a especificação do concreto bem da vida pretendido a ser outorgado ao demandante caso se dê o êxito da sua demanda. 
O pedido consiste naquilo que se postula ao Poder Judiciário, ante a causa de pedir. Assim, a causa de pedir é a razão da demanda, enquanto o pedido é a própria pretensão levada ao juiz.

A legislação processual brasileira, no artigo 286 do Código de Processo Civil, dispõe que os pedidos, a princípio, devem ser certos e determinados.

Embora o referido artigo, impropriamente, tenha utilizado textualmente a expressão "ou”, a certeza e determinação são grandezas cumuláveis e não excludentes.

$O$ pedido é certo porque deve estar explícito, tanto quanto ao objeto imediato (provimento jurisdicional que se pede) e mediato (bem da vida que se quer alcançar com o provimento jurisdicional). A determinação diz respeito à extensão ou limite do pedido.

É impossivel a existência de pedido incerto, porém, quanto à determinação, o pedido pode ser determinado ou determinável, ou seja, genérico.

O pedido genérico, consagrado nos incisos I a III do artigo 286 do Código de Processo, ocorre quando o objeto mediato será determinável, já que se define o an debeatur, mas não o quantum debeatur, que dependerá de posterior liquidação.

Tolera-se o pedido genérico nos casos em que o objeto for constituido por uma universalidade de bens ou quantia cobrada a título de indenização, bem como quando o valor a ser determinado depende de alguma conduta do réu.

Não se deve confundir pedido genérico com pedido vago, vez que aquele sem chegar a perfeita quantidade dos bens pretendidos, deixa delimitados desde logo os elementos e critérios dos quais se extrairá o montante da obrigação, o que o pedido vago nem mesmo indica.

Via de regra, os pedidos devem ser interpretados restritivamente, porém o Código de Processo Civil, no artigo 293, deixa em aberto algumas possibilidades para que sejam deferidos pedidos implícitos, isto é, que não foram postulados direta e expressamente na demanda.

Podemos apontar as seguintes ressalvas quanto à sobredita regra: juros legais (art. 293), juros de mora (art. 219)', correção monetária (atualização da moeda), despesas processuais e honorários advocatícios (art. 20) e prestaçôes sucessivas (art. 290).

Afora as hipóteses aduzidas, ao demandante incumbe o ônus de pedir de modo explícito o reconhecimento dos direitos principais e acessórios, sob pena de não ver o pronunciamento judicial atendê-los.

'Súmula 254 do STF: "Incluem-se os juros noratórios na liquidação, embora omisso o pedido ou a condenação." 
Do que se foi exposto, observa-se que cada pretensão terá as suas questões litigiosas, cujo conjunto delas formará a causa de pedir, que adicionado ao pedido, delimitado pela parte, irão definir a demanda.

Dos elementos constitutivos da demanda o de menor relevância é a fundamentação jurídica do pedido, por se tratar de mera proposta de enquadramento do fato na legislação, que pode ser altera pelo juiz quando da solução definitiva do litígio.

Os outros cinco elementos não podem ser alterados quando estabilizada a demanda, o que se dá com o saneamento do processo, bem como o juiz não pode exorbitá-los (artigos 264 e 294 do Código de Processo Civil).

\subsection{Cumulação de Demandas}

A cumulação de demandas visa propiciar julgamentos coerentes e o maior aproveitamento possível das atividades processuais envolvendo mais de duas pessoas, mais de uma pretensão ou mais de uma linha de fundamento em prol da pretensão.

Justifica-se o cúmulo de demandas pelo princípio da economia processual, resolvendo o maior número de pretensões num mesmo processo.

O cúmulo de demandas pode ser classificado como objetivo (cúmulo de pedidos e cúmulo de fundamentos) e subjetivo (litisconsórcio).

O cúmulo de pedidos está disciplinado pelo artigo 292 do Código de Processo Civil, correspondendo à soma de dois ou vários pedidos, se o demandante e o demandado forem os mesmos (desnecessária a conexão), não se exigindo qualquer liame fático ou jurídico entre os pedidos, nem entre os seus fundamentos.

O demandante deduz expressamente à vontade de obter mais de um resultado através do processo, indicando a justaposição de pretensões que poderiam ser deduzidas em processos distintos.

Embora o cúmulo de pedidos seja de grande abrangência, devem ser observadas três compatibilidades (artigo 292, § 1ª do Código de Processo Civil): compatibilidade entre os pedidos, compatibilidade de competências e compatibilidade procedimental.

A compatibilidade entre os pedidos decorre do fato de que os pedidos que se excluem, repelem-se reciprocamente, e não podem conviver na mesma demanda.

É caso de indeferimento da inicial a cumulação de pedidos incompatíveis, consoante se infere do artigo 295, parágrafo único, inciso IV do Código de Processo Civil, devendo ser oportunizada a escolha dos pedidos ao demandante antes do indeferimento, que só ocorrerá se não feita a escolha no prazo assinalado. 
Năo há que se falar no cúmulo de pedidos caso não exista identidade de competências, principalmente quando se tratar de competência absoluta, que não é passivel de prorrogação.

Quanto à compatibilidade procedimental, versa a legislação que o mesmo tipo de procedimento deve ser adequado para todos os pedidos, pois a simultânea realização de atos inerentes a mais de um procedimento no processo seria fonte de tumultos.

$\mathrm{O} \S 2^{a}$ do artigo 292 do Código de Processo Civil mitiga a regra geral de indisponibilidade do procedimento, permitindo que o demandante opte pelo procedimento ordinário para o processamento das demandas cumuladas, renunciando a sumariedade ou a especialidade de um dos pedidos para remover a incompatibilidade procedimental do cúmulo de pedidos.

Pode ocorrer o cúmulo sucessivo de pedido quando o pedido subseqüente será analisado na improcedência do pedido antecedente, ou seja, o primeiro pedido é prejudicial ao segundo, representando a sucessividade de julgamento, inerentes a prejudicialidade.

Possível, ainda, o cúmulo alternativo de pedidos, com a reunião de dois ou mais pedidos em uma só iniciativa processual para que apenas um deles seja acolhido, quando, ante o reflexo do direito material, a obrigação pode ser cumprida de mais de uma forma.

$O$ cúmulo de fundamentos numa mesma demanda dá-se quando se reúnem dois ou mais fundamentos para embasar a mesma pretensão.

Nesses casos o juiz pode conceder a tutela mediante o acolhimento de todos os fundamentos colacionados pelo demandante ou com base em apenas um deles.

A possibilidade do cúmulo de fundamentos decorre indiretamente do artigo 515 do Código de Processo Civil que indica a devolução ao Tribunal de toda a matéria tratada nos autos ainda que a sentença acolha apenas um dos fundamentos do pedido ou da defesa.

Já o cúmulo subjetivo ocorre no caso em que dois ou mais sujeitos integram o pólo ativo, o passivo ou ambos os pólos da relação processual, tal qual se dá nas hipóteses de litisconsorte.

\section{Resposta}

\subsection{Conceito}

As garantias asseguradas durante o processo às partes restam também em garantias do justo processo, onde temos a obrigatoriedade de informação e a possibilidade de reação à demanda que foi proposta. 
Ora, ao ser apresentada uma demanda, em estrita obediência ao prin-cípio do devido processo legal, cabe oportunizar ao demandado aduzir as razões da sua resistência à pretensão do demandante, o que se dá por meio da resposta.

Destarte, o acolhimento do pedido do autor importa no reconhecimento da juridicidade de sua pretensão e leva, assim, a interferir na esfera jurídica do réu, cuja liberdade sofre uma limitação ou uma vinculação de direito, imposta pelo Estado por meio da decisão judicial.

A demanda apresenta-se, pois, segundo essa concepção, como o pedido que uma pessoa faz ao órgão jurisdicional destinado a cessar a resistência de outra pessoa, operando na sua esfera jurídica em virtude da norma individual e concreta emanada do Poder Judiciário.

A direção contrária dos interesses dos demandantes acarreta a bilateralidade do processo, ou seja, a cada demanda inicial ou incidental do demandante existirá a correspondente demanda do demandado, que se materializa pela resposta.

Assim, o demandado também tem uma pretensão em face dos órgãos jurisdicionais, qual seja: que a pretensão do demandante seja rejeitada.

Ressalte-se que a posição de demandante é apenas uma questão de oportunidade e agilidade, pois tanto o demandante quanto o demandado possuem uma pretensão resistida a ser apresentada para solução pelo Estado-Juiz, sendo que aquele que primeiro protocolar sua demanda junto ao órgão judicial assumirá a posição de demandante.

A citação do demandado dá ciência da ação e chama-o para apresentar sua resposta, com a oportunidade de opor as razões que tiver à pretensão que o demandante faz contra si.

O chamamento a juízo do demandado, contido na citação, corresponde à oportunidade que a lei dá ao demandado de se defender.

A garantia do contraditório engloba, ao demandante, a possibilidade de poder deduzir sua pretensão em juízo, alegar e provar fatos constitutivos do seu direito e, quanto ao demandado, ser informado sobre a existência e conteúdo da demanda e poder reagir, isto é, fazer-se ouvir, provando, se necessário, fatos modificativos, extintivos ou impeditivos do direito do demandante.

Invocar a tutela jurisdicional para que atue de acordo com a sua resistência à demanda também é direito daquele contra quem se age, ou seja, do demandado.

Opróprio Código de Processo Civil consagra a assertiva de que o demandado tem direito a tutela jurisdicional ao dispor, no artigo $267, \S 4$, que após a citação do demandado, o demandante só poderá desistir da demanda com a anuência daquele. 
A resposta corresponde ao direito de pedir que a tutela jurisdicional requerida pelo demandante seja denegada por não se conformar com o direito material, declarando-se a inexistência da relação jurídica afirmada pelo demandante através de uma sentença declaratória negativa.

Portanto, o juiz não se encontra apenas diante da demanda do demandante, mas ao mesmo tempo diante da demanda contraposta do demandado.

A legislação processual, via de regra, concede o prazo de quinze dias para que o demandado adote alguma atitude ante a demanda aduzida.

Caso exista, na relação processual, mais de um demandado em um dos seus pólos, todos representados pelo mesmo advogado, o prazo geral para responder a demanda não se altera. Contudo, se os demandados forem representados em juízo por procuradores distintos, computar-se-á em dobro o prazo para a resposta, cujo termo inicial será a última citação.

Quando o demandado for a Fazenda Pública, autarquia ou fundação pública o prazo para a apresentação da resposta será em quádruplo.

$\mathrm{Na}$ hipótese em que se conjugarem as duas situações, ou seja, o demandado for a Fazenda Pública, autarquia ou fundação pública representados por diferentes procuradores, o prazo para resposta será oito vezes maior que o normal, já que se faz necessário combinar ambas as regras, qual seja o prazo em dobro e em quádruplo.

A solução apresentada não é pacifica, pois existe corrente doutrinária que indica a necessidade de opção pelo beneficio temporal mais benéfico, não admitindo a combinação das regras.

Podemos elencar as seguintes manifestações do demandado quanto à demanda do demandante, que passaremos a analisar pormenorizadamente: inércia, aquiescência à pretensão exposta pelo autor, apresentação de defesa (processual ou de mérito) e formulação de pretensão (reconvenção).

\subsection{Revelia}

Integrar a relação jurídica processual acarreta uma série de ônus as partes, que objetivam garantir o desenvolvimento regular do processo, culminando com a entrega da prestação jurisdicional, sendo que do inadimplemento do encargo advém uma desvantagem processual.

Não poderia ser diferente, pois a falta de limitação de oportunidade e tempo para a prática dos atos processuais acabariam por eternizar os conflitos de interesses, vez que restariam desorientados pelo interesse e, 
ora, desinteresse das partes de que a marcha processual fluisse, encontrando um termo.

Assim, foi instituído o prazo peremptório para que o réu exerça o ônus de oferecer resposta à pretensão aduzida pelo autor, sob pena da extemporaneidade ou intempestividade do ato e imposição da revelia, consubstanciada na situação em que se encontra o réu que não atende ao chamamento judicial.

A revelia corresponde a atitude do réu que permanece silente no prazo para responder a demanda, já que a defesa é um ônus seu e não um dever.

Vale indicar que a revelia se diferencia diante do procedimento que se adota no processo. No procedimento ordinário a revelia se dá pela falta de defesa no prazo estatuído pela legislação, já no procedimento sumário a revelia é fruto da ausência injustificada do réu à audiência preliminar e da não apresentação de defesa.

A conseqüência negativa, fruto da inércia, consagra-se na presunção de veracidade dos fatos afirmados pelo autor na inicial, bem como na desnecessidade do revel ser intimado dos atos processuais subseqüentes até sua futura intervenção no processo, conforme artigos 334 , IV e 322 do Código de Processo Civil Brasileiro.

Assim, os efeitos da revelia podem ser materiais ou processuais. Os efeitos de ordem material influenciam na resolução do mérito da ação, ante a presunção de veracidade dos fatos afirmados pelo autor, nos termos do artigo 319 do Código de Processo Civil, sem que haja, contudo, presunção em relação às afirmações de direito.

Já os efeitos da revelia de ordem processual influenciam na relação jurídica processual, gerando o julgamento antecipado da lide e prosseguimento do processo sem a intimação do revel, consoante os artigos $330 \mathrm{e}$ 322 do Código de Processo Civil.

Com efeito, o julgamento antecipado do processo decorrente da revelia, que acarreta a dispensa da fase instrutória do processo, não ocorrerá caso o réu, apesar de não ter oferecido contestação, ofereça algum outro tipo de resposta, como, por exemplo, reconvenção ou exceção, que deverá ser analisada na mesma decisão.

Da mesma forma, a dispensa de intimação do réu dos atos processuais do revel não implica no impedimento de que ele venha a ingressar no processo em andamento. Porém, o ingresso tardio na demanda não the devolve a faculdade de praticar os atos processuais já vencidos. 
O revel retoma o processo, então, no estado em que se encontrar, não podendo mais realizar atos de fases processuais pretéritas.

Ainda que não compareça em momento algum no processo, apesar de regularmente citado, o revel deverá ser intimado da decisão prolatada, nos mesmos termos em que é exigida a ciência do autor, podendo exercer o duplo grau de jurisdição caso entenda necessário.

Ressalte-se que a revelia é uma conseqüencia processual pelo não cumprimento do ônus, que gera reflexos probatórios, o que não implica necessariamente na procedência do pedido. A constatação da revelia não induz que os seus efeitos materiais irão operar.

Há a revelia (ausência de defesa), mas não se verificam seus efeitos, nas hipóteses indicadas pelo artigo 320 do Código de Processo Civil, quais sejam: existência de litisconsórcio passivo, no qual um dos litisconsortes tenha contestado a ação aduzindo fatos comuns a todos os outros; litígios que versem sobre direitos indisponíveis (objeto não possível de ser transacionado); e se a petição inicial não está acompanhada do instrumento público que a lei considera indispensável à prova do ato (requisito para a sua validade).

No caso do litisconsorte que responde a demanda faz-se necessário que ocorra uniformidade de fatos para que o revel seja beneficiado pela defesa, afastando os efeitos da revelia, pois a decisão terá que analisar os fatos em comum daquele que ofereceu a contestação e do litisconsorte revel.

Importa indicar que no caso de direitos indisponíveis deve-se observar a titularidade do mesmo, já que se ele for do autor dar-se-ão os efeitos da revelia.

Se o titular do direito indisponível não pode validamente alienar o seu direito, mesmo fora do processo, seria contraditório permitir que de maneira indireta, pela revelia, a disposição fosse possível, o que facultaria a fraude.

Podemos apontar outros óbices aos efeitos da revelia: nomeação de curador especial (artigo $9^{a}$ do Código de Processo Civil), apresentação de contestação pelo assistente simples do revel (artigo 52, parágrafo único do Código de Processo Civil) ou se o réu apresentar apenas outro tipo de resposta (reconvenção, por exemplo), a qual, tomada em seu conjunto, é incompatível com a presunção de veracidade.

Portanto, toda presunção não pode ser vista de maneira absoluta, mas sim dentro da relatividade que a cerca, já que a veracidade dos fatos afirmados pelo autor cede se o contrário resultar da prova dos autos. A presunção de veracidade deve ser vista em confronto com a verossimilhança e coerência das demais provas encartadas ao processo. 


\subsection{Reconhecimento Jurídico do Pedido}

O reconhecimento da procedência da pretensão do autor ocorre quando na defesa o réu aponta expressamente que assiste razão a pretensão do autor, não se opondo a ela.

Ao ser citado da demanda, o réu pode concluir que assiste razão a pretensão do autor e que a sua resistência é injustificada indicando tal fato expressamente na resposta, acabando, então, por reconhecer a procedência do pedido.

O reconhecimento jurídico do pedido vai além dos efeitos da revelia, onde apenas os fatos aduzidos pelo autor serão presumidos como verdadeiros, pois implica na admissão como legítimos os fatos e o direito que se apontou como incidente sobre os mesmos.

Resta excluída a possibilidade de se reconhecer o pedido do autor caso a demanda verse sobre direitos indisponíveis.

Não há qualquer manifestação de conhecimento, mas pura manifestação de vontade do réu de submeter-se ao pedido contra si formulado pelo autor, limitando o juiz em homologar por sentença o ato do réu para que possa surtir seus efeitos legais, decidindo o mérito da causa, de modo a impedir que se renove a pretensão em futura demanda.

\subsection{Defesa}

A defesa se consubstancia na atitude do réu de se opor à pretensão do autor, discordando de se submeter a ela.

Via de regra a defesa deve ser apresentada por escrito. Contudo, o artigo 278 do Código de Processo Civil autoriza a resposta oral nas causas submetidas ao procedimento sumário.

Dentre os princípios que norteiam a defesa interessa apontar o da concentração, do ônus da impugnação específica e da eventualidade.

Segundo o princípio da concentração da defesa, toda a matéria de defesa deve ser alegada em contestação, que tem caráter preclusivo. Com o oferecimento da defesa o réu não pode deduzir novas alegações, salvo se relativas a direito superveniente.

O princípio da eventualidade assevera que o réu pode fazer alegações sucessivas e contraditórias entre si para se defender, cabendo ao juiz, em não acolhendo uma alegação, passar ao exame da outra, já que a concentração é a marca determinante da mesma, não cabendo posteriormente a sua apresentação complementá-la. 
O princípio do ônus da impugnação específica indica que é vedada a contestação genérica, devendo o réu impugnar um a um os fatos articulados pelo autor na petição inicial, sob pena de se operar a confissão quanto a fato não repelido pelo réu. Os fatos alegados pelo autor não impugnados serão tidos como verdadeiros, sendo desnecessária a produção de provas, já que sobre eles não surge controvérsia.

A oposição à pretensão do demandante pode ocorrer por meio da contestação, que é a peça de defesa por excelência negando a procedência da mesma, ou de exceções processuais, que se limitam às matérias de incompetência relativa, suspeição e impedimento do juízo.

Podemos classificar, então, as defesas em processuais, que atacam o instrumento para a obtenção do bem da vida, e em substanciais ou de mérito, que implicam na resistência do réu ao pedido mediato do autor, isto é, ao bem da vida postulado.

Conforme as defesas processuais gerem ou não a extinção do processo sem exame de mérito, podemos efetuar outra classificação: defesa processual própria ou peremptória, que põe fim à relação processual se reconhecida, impedindo o exame do mérito em função de um defeito processual insanável, consubstanciando-se nas hipóteses elencadas no artigo 267 do Código de Processo Civil; e defesa processual imprópria ou dilatória, que buscam adequar a relação processual, para que se dê um julgamento mais correto do mérito da causa, sem acarretar a extinção do processo, como nos casos de exceção de incompetência, impedimento e suspeição do juízo.

As defesas materiais recebem, também, uma subdivisão de relevância essencial no que atine ao ônus da prova: defesa material direta e defesa material indireta.

$\mathrm{Na}$ defesa material direta o réu nega diretamente os fatos apresentados pelo autor, não aumentando, então, o conteúdo fático da demanda inicial, já na defesa material indireta, o réu não nega os fatos apresentados pelo autor, mas lança mão de causa extintivas, modificativas ou impeditivas dos atos articulados na inicial, atraindo para si o ônus da prova de tais fatos.

\subsection{Reconvenção}

Uma das modalidades de resposta que pode ser aduzida pelo demandado é a reconvenção, que é ação do réu contra o autor proposta no mesmo feito em que é demandado, ensejando a cumulação objetiva ulterior de ações dentro da mesma relação processual. 
Na reconvenção o réu deixa a posição passiva que lhe foi atribuída quando da propositura da demanda, passando a ser titular da demanda em face do primitivo autor. O réu da defesa, passa para o ataque ao autor.

$\mathrm{Na}$ demanda inicialmente proposta pelo autor justapõe-se, no mesmo processo, outra de iniciativa do réu.

Contudo, a reconvenção não substitui a defesa, já que mesmo no caso do réu aduzi-la, caberá impugnar o pedido da ação principal para que não se opere a confissão.

Trata-se de um contra-ataque do réu ao autor, que expande o processo para conter duas lides, a originária e a reconvencional, que serão julgadas na mesma sentença.

A reconvenção não é obrigatória, podendo o réu aduzir sua pretensão em processo separado, ajuizando uma ação autônoma. A cumulação das demandas em um único processo funda-se no princípio da economia processual e fica a critério do réu, que poderá provocar a tutela jurisdicional no mesmo processo em que é demandado ou formar mais uma relação processual em outra demanda.

É uma ação autônoma, não estando sujeita ao destino da ação principal, restando unidas pela conexão, sendo que no caso do autor desistir da ação principal, o processo prosseguirá para solucionar a ação reconvencional.

Sendo uma demanda do réu contra o autor, necessário se faz na reconvenção a observância de todos os requisitos que a legislação processual indica para a propositura de uma ação autônoma.

A reconvenção deve se amoldar a alguns pressupostos de admissibilidade, caso contrário, o réu deverá ajuizar ação própria em um outro processo.

Os pressupostos de admissibilidade da reconvenção são conexão, competência, procedimento idêntico, legitimidade e litispendência. Expliquemos.

Para que seja admitida a reconvenção deve existir conexão com a ação principal ou com o fundamento da defesa, seja a causa de pedir da ação principal, o pedido da ação principal ou a defesa do réu na ação principal.

A ação e a reconvenção serão julgadas na mesma sentença, daí o juiz da causa principal não pode ser absolutamente incompetente para julgar a reconvenção, sob pena da não admissibilidade da mesma.

Por serem ações que tramitarão paralelamente, faz-se necessária à compatibilidade de ritos entre a reconvenção e a ação principal.

Somente entre as mesmas partes ocorrerá à reconvenção, não podendo ser trazida parte inexistente na ação principal, ampliando um dos pólos processuais. 
Por fim, a reconvenção pressupõe processo pendente para que possa nele tramitar e ser julgado pela mesma sentença.

Quanto ao procedimento, deve-se observar o prazo da propositura da reconvenção, que é o mesmo da contestação, devendo ser oferecidas simultaneamente em peças autônomas.

O réu não precisa contestar para reconvir, mas se quiser fazê-lo há de oferecer no mesmo ato a reconvenção e a contestação, sob pena de se operar a preclusão. Assim, ainda que o réu não utilize completamente o prazo para contestar, se vier a apresentar a peça de defesa antes do termo final, incabivel será o ajuizamento da reconvenção posteriormente, mesmo que antes de escoado completamente o prazo para tanto, pois se exige a simultaneidade dos atos.

Não é possível, também, a reconvenção da reconvenção, pois o artigo 316 do Código de Processo Civil indica que o reconvindo será intimado para contestar a ação reconvencional e não para aduzir nova resposta, o que poderia, então, englobar a referida medida.

Ademais ao se admitir a propositura de reconvenção de outra reconvenção à finalidade do instituto estaria sendo relegada, já que estragaria seu próprio fundamento de economia processual.

Após a contestação da reconvenção, o procedimento da ação principal e da reconvencional se uniformiza, com uma única instrução processual e sentença, sendo que cada capítulo da decisão julgará as respectivas ações, podendo ocorrer a compensação das condenações, ante a procedência de ambas as pretensões.

\section{Conclusão}

A perspectiva do processo como uma tutela bilateral implica em aceitar a assertiva que tanto o autor, como o réu, possuem uma demanda que está sendo deduzida em juízo.

O autor quer que a resistência do réu seja declarada injustificada e cesse. Por seu turno, o réu pretende a declaração de que é justa a sua oposição.

Usualmente denomina-se demanda e resposta o binômio corresponde à demanda inicial do autor e a demanda inicial do réu, respectivamente.

A contraposição de pretensões é que obriga ao Estado-Juiz intervir para que, imparcialmente, indique, com fundamento no Ordenamento Jurídico, qual postura deve prevalecer. 
Assim como o demandante não é obrigado deduzir sua pretensão $\mathrm{em}$ juízo, tanto que a jurisdição é inerte e aguarda a sua provocação, não é exigido ao demandado que se discorde da demanda a qual está sendo submetido.

A finalidade do processo é a pacificação e não fomentar a discórdia. Daí, a legislação processual contenta-se em oportunizar que o demandado se manifeste quanto à demanda do autor, o que pode se dar pela inércia, aquiescência à pretensão exposta, apresentação de defesa ou mesmo com a formulação de nova pretensão via reconvenção.

Destarte, não há que se negar que a postura do demandado lhe acarretará efeitos na sua órbita jurídica, cabendo a ele a escolha pela conduta mais conveniente, apesar das consequêencias da mesma serem impostas pela legislação coercitivamente.

Contudo, na constante busca pela verdade material, atualmente, incumbe ao Juiz se cercar dos instrumentos legais para a busca do justo, não como mero espectador do processo, compatibilizando os poderes dispositivos das partes com os seus poderes inquisitórios, assumindo uma postura ativa na relação jurídica processual.

Após a provocação da jurisdição, a justa solução da demanda não mais interessa apenas as partes, mas sim a toda sociedade, que representada pelo Poder Judiciário erradicará o conflito.

Portanto, o juiz parcial não se coaduna com a relação processual, que necessita de um juiz partícipe, sem que para isso extrapole os poderes que já lhe são conferidos pela legislação processual em vigor.

\section{BIBLIOGRAFIA}

ARRUDA ALVIM, Manual de direito processual civil. Revista dos Tribunais: São Paulo, 1997, vol. 1, 60 ed.

ASSIS, Araken de, Cumulação de ações. Revista dos Tribunais: São Paulo, $1995,2^{\circ}$ ed.

BAPTISTA DA SILVA, Ovídio A. Curso de Processo Civil - Processo de Conhecimento. Revista do Tribunais: São Paulo, 2000, vol. 1, 5o ed.

BARBI, Celso Agrícola, Comentários ao Código de Processo Civil. Forense: Rio de Janeiro, 1997, vol. I, $10^{\circ} \mathrm{ed}$.

BARROSO, Carlos Eduardo F. de Mattos, Teoria Geral do Processo e Processo de Conhecimento: Saraiva, São Paulo, 1997.

BERMUDES, Sérgio, Introdução do processo civil. Forense: Rio de Janeiro, 1995. CINTRA, Antônio Carlos de Araújo, et alli. Teoria Geral do Processo: Malheiros, São Paulo, 1995, $9^{\circ}$ ed. 
DINIZ, Maria Helena, Dicionário Jurídico. Saraiva: São Paulo, 1998, vol. 1. DINAMARCO, Cândido Rangel, $A$ instrumentalidade do processo. Malheiros: São Paulo, 1996.

Paulo, 2001.

, Instituições de Direito Processual Civil. Malheiros: São

GRECO FILHO, Vicente, Direito processual civil brasileiro, São Paulo: Saraiva, 1999 , vol. 2 . 13.ed.

LIEBMAN, Enrico Tulio, Manual de Processo Civil (traduzido e anotado por Cândido Rangel Dinamarco). Forense: Rio de Janeiro, 1984.

MARINONI, Luiz Guilherme, Novas linhas do processo civil. Malheiros: São Paulo, $1996,2^{\circ} \mathrm{ed}$.

Manual do processo de conhecimento: a tutela jurisdicional através do processo de conhcimento. Revista dos Tribunais: São Paulo, 2001.

MIRANDA, Francisco Cavalcanti Pontes de, Tratado das Ações. Revista dos Tribunais: São Paulo, 1974.

MIRANDA, Pontes de, Comentários ao Código de Processo Civil. Forense: Rio de Janeiro, Forense, 1996.

MOREIRA, José Carlos Barbosa, O novo processo civil brasileiro: exposição sistemática do procedimento. Forense: Rio de Janeiro, $1999,20^{\circ} \mathrm{ed}$.

NERY JUNIOR, Nelson, Código de processo civil comentado e legislação processual civil extravagante em vigor. Revista dos Tribunais: São Paulo, 2001, $5^{\circ}$ ed.

NEGRÃO, Theotonio, Código de processo civil e legislação processual em vigor. Saraiva: São Paulo, 2000, 31ำ ed.

PASSOS, José Joaquim Calmon de, Comentários ao Código de Processo Civil. Forense: Rio de Janeiro, 1998, $8^{\circ} \mathrm{ed}$.

PAULA, Alexandre de, Código de processo civil anotado. Revista dos Tribunais: São Paulo, $1994,6^{\circ}$ ed.

SANTOS, Ernane Fidélis dos, Manual de direito processual civil. Saraiva: São Paulo, 1996, vol. I, $4^{\circ} \mathrm{ed}$.

SANTOS, Moacyr Amaral, Primeiras Linhas de direito processual civil. Saraiva: São Paulo, $1999,20^{\circ} \mathrm{ed}$.

SILVA, Ovídio A. Batista da, Curso de Processo Civil. Revista dos Tribunais: São Paulo, 2000, 5.․ ed.

THEODORO JÚNIOR, Humberto. Curso de Direito Processual Civil. Forense: Rio de Janeiro, 2000.

WAMBIER, Luiz Rodrigues, Curso Avançado de Processo Civil. Revista dos Tribunais: São Paulo, 2002.

WATANABE, Kazuo, Da Cognição no Processo Civil. Central de Publicações Jurídicas: São Paulo, $1999,2^{2}$ ed. 